ENTREPRENEURSHIP AND SUSTAINABILITY ISSUES

ISSN 2345-0282 (online) http://jssidoi.org/jesi/

2021 Volume 8 Number 4 (June)

http://doi.org/10.9770/jesi.2021.8.4(33)

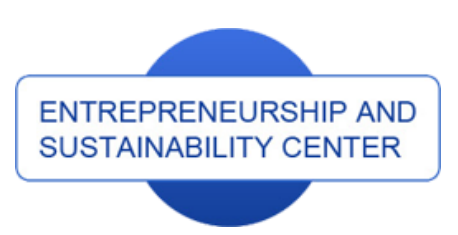

Publisher

$\underline{\text { http://jssidoi.org/esc/home }}$
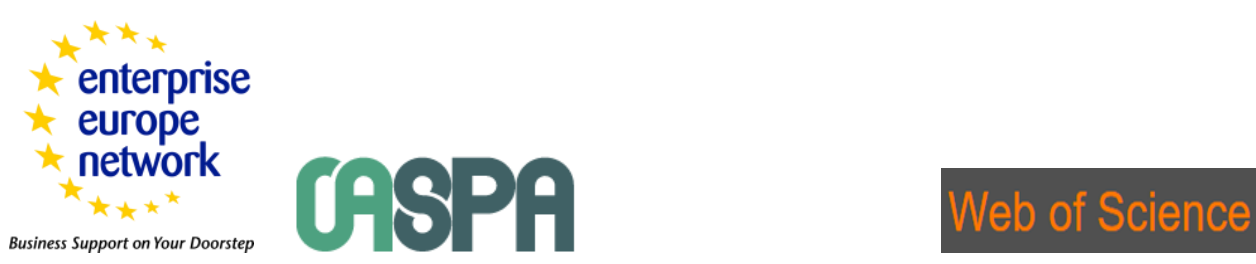

1) Clarivate

Analytics

\title{
EMPLOYMENT OF FOREIGN STUDENTS AFTER GRADUATION IN HUNGARY IN THE CONTEXT OF ENTREPRENEURSHIP AND SUSTAINABILITY
}

\author{
Janka Betáková ${ }^{1}$, Jingjing Wu ${ }^{2}$, Ildiko Rudnak ${ }^{3}$, Robert Magda ${ }^{4}$ \\ ${ }^{1}$ DTI University, Sládkovičova ul. 533/20, Dubnica nad Váhom, 018 41, Slovakia \\ ${ }^{2,3,4}$ Szent István University, Páter K. u. 1, 2100 Gödöllö, Hungary \\ ${ }^{4}$ Vanderbijlpark Campus, North-West University, Vanderbijlpark 1900, South Africa
}

E-mails: ${ }^{1}$ betakova@dti.sk ${ }^{2}$ rmagda72@gmail.com; ${ }^{3}$ Rudnak.Ildiko@szie.hu; ${ }^{4}$ jingjing.wu.jj@gmail.com

Received 15 January 2021; accepted 20 April 2021; published 30 June 2021

\begin{abstract}
In recent decades, more and more international students, including paid and scholarship-funded students coming to study in Hungary, most of them are studying in higher education institutions. The experience of studying abroad has not only broadened foreign students' horizons, but also increased their entrepreneurial awareness to a certain extent, especially increased the number of foreign companies or businesses set up by foreign students to trade and cooperate with the host country. In this sense, they are moving forward to entrepreneurship. At the same time, entrepreneurial and sustainable education in universities also play a very important role in the development of international students' awareness. After graduation, some international students choose to stay and work in Hungary, while others choose to return to their home countries or work in other countries. The present study was conducted to understand whether overseas experience has sustainable influences on career development and employment choice of foreign students, testing whether their employment intentions have changed after studying in Hungary. Furthermore, whether international students' attributes have relationships with their employment intentions. In addition, it is necessary to explore the main reasons for choosing different employment intentions. For data analysis, descriptive statistics, Paired Sample T-test and Crosstabulation were used in SPSS. The overall results show that the experience of studying abroad does have a sustainable impact on the employment intention of foreign students, but due to the different attributes of foreign students, the reasons, effects and degrees of the influence are different.
\end{abstract}

Keywords: employment intentions; career choice; foreign students in Hungary; attributes of foreign students; entrepreneurship and sustainability

Reference to this paper should be made as follows: Betáková, J., Wu, J., Rudnak, I., Magda, R. 2021. Employment of foreign students after graduation in Hungary in the context of entrepreneurship and sustainability. Entrepreneurship and Sustainability Issues, 8(4), 553570. http://doi.org/10.9770/jesi.2021.8.4(33)

JEL Classifications: I23, L26, J80 


\section{ENTREPRENEURSHIP AND SUSTAINABILITY ISSUES}

ISSN 2345-0282 (online) http://jssidoi.org/jesi/

2021 Volume 8 Number 4 (June)

http://doi.org/10.9770/jesi.2021.8.4(33)

\section{Introduction}

Globalization provides rich new opportunities for higher education. The flow of international students is increasing, and every year more students are studying in universities outside their home countries. One result is the development of global universities, with students coming from a wide range of national, ethnic and cultural traditions. Today's universities are one of the most diverse organizations in the world, with representatives from dozens of countries among students, faculty and support staff (Harrison, 2012). One of the powerful driving forces behind internationalization of higher education in Europe is the goal of European labour markets aimed at creating a competitive labour market: companies are interested in recruiting talented people from larger labour forces (Tempus Public Foundation, 2018). On the opposite side, the research of Srovnalikova et al. (2018) showed that students are more interested in gathering practical information about business services that are relevant to business, or even more about gaining employment in information and communication companies. In addition, students with working experience in foreign countries are more likely to become self-employed and their proficiency in information and communication technology will also be improved (Pinto, 2020). Here, to succeed in an internationally competitive labour market, education must be strategically planned and adequate resources must be fully utilized (Tempus Public Foundation, 2018). Furthermore, it needs to be emphasized that interuniversity mobility programs (such as the Erasmus Project) encourage more students to study abroad and have a causal and positive impact on becoming entrepreneurs (Pinto, 2020). This is because mastering a foreign language has a special impact on university students, who are positioned by the market as migrant workers with entrepreneurial spirit (Sabaté-Dalmau, 2020). At the same time, the overseas study program contributes to the sustainable development of education, that is, educational institutions make great efforts to adjust the management model, human capital and technology, as well as curriculum to meet the needs of mobile students (Bañegil-Palacios \& Sánchez-Hernández, 2018).

Mosneaga \& Winther (2013) believe that in the global competition for talent, international students are regarded as potential skilled workers. However, due to nationalism or national protectionism in some Western countries, international students are forced to return to their home countries (Xiong \& Mok, 2020). Nor is it a policy goal for Hungary to retain international students here. International students will return to their motherland and disseminate good reputations for higher education in Hungary and promote Hungary's scientific economic and cultural links with each third country (European Migration Network, 2018). Here, according to European internationalization labour market demand, for enterprises to recruit internationally outstanding talents and Hungary retain international students as not a policy goal, we need to explore what is currently employment intentions of international students in Hungary. Whether they prefer to join the international labour market of Hungary or they are more likely to return to their home country or go to other foreign countries. Moreover, what kind of international students would be more willing to choose which employment intention? Whether international students' employment intentions have great relationships with their attributes and what are the main reasons of them to have different employment intentions, as well as the influence of studying abroad and university education on the entrepreneurship and sustainability of foreign students. In addition, our goal is to extend the present research to the V4 countries (Poland, Hungary, the Czech Republic and Slovakia) as well, as internationalization and the presence of international students are characteristic of all four countries, and further comparative studies with a number of sustainability-related findings may help innovative education in universities.

The research is based on the current international students in Hungary and collects data through a questionnaire survey. After analysis by SPSS software, the results show that the desire of international students to work in their own country does not change with the experience of studying in Hungary, but their desire to work in Hungary and other foreign countries have become stronger. Moreover, the age, working years and Hungarian proficiency of international students are the main attributes that affect their employment intentions. In addition, hoping to return to their own country to live is the main reason for returning to work. For employment in Hungary, international 


\section{ENTREPRENEURSHIP AND SUSTAINABILITY ISSUES}

ISSN 2345-0282 (online) http://jssidoi.org/jesi/

2021 Volume 8 Number 4 (June)

http://doi.org/10.9770/jesi.2021.8.4(33)

students like the working environment and atmosphere in Hungary as the most important reason. While, foreign students who want to work in other foreign countries are more likely to go to better countries for economic development and social security. As the research on present topic about foreign students in Hungary is still limited in literature, it is necessary to explore the current employment intentions of them. This paper could provide references for employment choice of foreign students in Hungary and these results can provide data basis for the Hungarian government, universities and enterprises to learn more about foreign graduate students in Hungary from the perspective of sustainable development.

First of all, this study reviews the literature to understand the international education background of Hungary, the employment intentions and entrepreneurship of international students. Secondly, the methods and sample data used in this study are described in detail. Here, the collected data is analyzed mainly through descriptive statistics, Paired Sample T-test and Crosstabulation. After that, the research results are presented and compared with previous studies as well as discussed in depth. Finally, combined with the research results, this paper gives the research conclusions and suggestions.

\section{Theoretical background}

\subsection{International educational background in Hungary}

The premise of internationalization undoubtedly assumes that geographical mobility (such as the form of student study abroad programs) promotes the favorable success of higher education (HE) and increases the likelihood of career development (Sabaté-Dalmau, 2020). In addition, the traditional driving point for the demand for education, especially higher education (HE), is the realization of the expectation that it can improve the economic and social status of graduates (Mazzarol \& Soutar, 2002). Therefore, correspondingly, the international or foreign enrollment of higher education (HE) in the world is increasing year by year, reaching 5.6 million in 2018, of which 3.9 million are attracted by OECD countries and 1.7 million by Non-OECD countries. The largest group of international or foreign students at all levels of higher education (HE) is from Asia, accounting for 57 per cent of all migrant students in the OECD in 2018. And then, China and India account for the largest proportion of all migrant students enrolled in OECD countries, contributing more than 30 per cent. The United States is the top destination for international students in OECD countries, accounting for 18 per cent of the global education market, followed by Australia and the UK (8\% each) and Germany (6\%) (OECD, 2020).

In Europe, Erasmus+ is a financial tool used to support the flow of international students with social policy objectives (Tempus Public Foundation, 2018). It signed in 2019 funded the mobility of nearly 505,000 students and faculty in higher education (HE) in Europe and other parts of the world. The launch of a series of cooperative projects has promoted the better use of ICTs in learning and teaching, and further strengthened the close links between higher education institutions, employers and society as a whole (European Union, 2020). In addition, in 2013, the Hungarian Government established a scholarship program, Stipendium Hungaricum (Tempus Public Foundation, 2018). Since the turn of the century, the number of foreign citizens in higher education (HE) in Hungary has been on the rise. From 11,783 students in 2011 to the academic year 2019/2020, we have seen a 3.5fold increase in this number, which is $326 \%$ of the previous figure, that means there are 38,422 international students (Tempus Public Foundation, 2020). In the choice of majors, the proportion of foreign students in medical and agricultural education is higher, while the proportion in science and social sciences is relatively low. Among the international students participating in degree programs, China has the largest number of students, more than 1,000 . However, the growth rate of medical students is slowing, with German students accounting for the largest proportion of this group (Tempus Public Foundation, 2018). 


\section{ENTREPRENEURSHIP AND SUSTAINABILITY ISSUES}

ISSN 2345-0282 (online) http://jssidoi.org/jesi/

2021 Volume 8 Number 4 (June)

http://doi.org/10.9770/jesi.2021.8.4(33)

\subsection{Employment intentions of International students}

Compared with ever before, talent is also mobile. Many of the most talented people can make choices and are willing to move to any place where they can maximize their talent (Wang \& Liu, 2016). To some extent, the geographical mobility of all students combines the boundaries of academic and early career trajectories (SabatéDalmau, 2020). However, today's international students face decisions not only about where to work but also about their career decisions, including thoughtful consideration of the cultural factors of their home and host countries, lifestyle choices and thinking about a better future (Arthur \& Flynn, 2011). After that they may face a dilemma in their initial path choice because they want to seek the best future, or later when they realize that their first choice did not come true as expected (Tharenou, 2015). The career outcome and response of graduates who remain employed in the host country may affect whether they are repatriated or emigrated to a third country in the future (Tharenou, 2015).

The combination of international residential migration, labor market mobility and educational mobility can be seen as a conceptual study of staying abroad (Netz \& Jaksztat, 2017). Parey \& Waldinger (2011)'s results show that students' behaviour in labour market mobility decisions may be potentially affected by educational mobility programs. For example, Pinto (2020) found that the possibility of working abroad would be increased by participating in the Erasmus program while studying in Spain. Similarly, Kronholz \& Osborn (2016) believe that significant positive changes have taken place in the professional identity assessment reported by university students before and after studying abroad, such as the experience of studying abroad can expand students' opportunities to work and live abroad (Brooks et al., 2012), bring them positive returns, promote their job search and career development (Nilsson \& Ripmeester, 2016; Xiong \& Mok, 2020). However, Waibelet al. (2017) propose that only one-fourth or less of respondents reported any actual career changes after their stay abroad. This suggests that studying abroad may be more likely to reaffirm and advance a chosen career path than to cause individuals to fundamentally question their original career plans.

Brooks et al. (2012)'s research shows that many foreign students are more willing to cross their own borders and look for jobs and career development in other countries or regions with good opportunities. The results of the Imran et al. (2011)'s study of Pakistani medical graduates show that respondents want to emigrate because they believe that overseas training will have a positive impact on their future careers in order to have a competitive advantage in a saturated job market. This leads to economic security, better working conditions and training experience. In addition, Tharenou (2015) and Mosneaga \& Winther (2013) propose that culture shock and crosscultural adjustment are most likely to occur when international students first enter the host country and have been managed to a large extent during their studies. Therefore, the reasons why international students stay in the host country are more likely to be related to their employment and assimilation, rather than venturing to other places to start a new life.

Nevertheless, the reasons why international students leave the host country after graduation are more dominant in the job market and access to the job market (including the ability to speak local languages) than other factors (Nilsson \& Ripmeester, 2016). Some students return home with the human capital (knowledge) they have acquired abroad, perhaps for the sake of higher wages and family ties in their home country, or for the attraction of government incentives (Naito \& Zhao, 2020). In examining the trend of international human capital flows in China, it is noted that in the 2000s, China's economic success and subsequent social changes enabled China to effectively promote the flow from provider to recipient. As a result, China is now seen as a land full of opportunities and many overseas Chinese have returned to China (Gill, 2010). According to the statistics of Chinese Ministry of Education, the number of high-quality overseas Chinese graduates returning home has been growing steadily from 1978 to 2017 and a total of 3.132 million students returned home after graduation, accounting for 83.73 percent of the total number of students studying abroad (Ministry of Education, 2017). Grogger \& Hanson (2015) examined the location choices of foreign-born students after obtaining a doctorate from 


\section{ENTREPRENEURSHIP AND SUSTAINABILITY ISSUES}

ISSN 2345-0282 (online) http://jssidoi.org/jesi/

2021 Volume 8 Number 4 (June)

http://doi.org/10.9770/jesi.2021.8.4(33)

an American university and stated that if there is strong GDP growth in the US economy in recent years, or if GDP growth in the country where foreign students are born is weak, then foreign students are more likely to stay in the United States. Foreign students are less likely to stay in the United States if they come from a country with a higher average income or a country that has recently been democratized.

\subsection{Entrepreneurship of International students}

The establishment of enterprises is an important aspect of promoting national development, which helps to spread innovation, create jobs, improve competitiveness, enhance social cohesion and well-being, so entrepreneurial behavior has become an indispensable condition for economic growth (Fernandes et al., 2018). Pinto (2020)'s research shows that participating in the Erasmus project has a causal and positive impact on becoming an entrepreneur. This is due to the mastery of foreign languages has a special impact on university students, who are positioned by the market as mobile employees with entrepreneurial spirit. Their employment opportunities depend on their self-fulfilling competitiveness and flexibility in the mobile market as well as their sense of selfresponsibility for foreign language skills (Sabaté-Dalmau, 2020).

In addition education policy plays a vital role in fostering and promoting graduates' entrepreneurial intentions (Wu \& Wu, 2008; Pinto, 2020; Tung et al., 2020; Omer \& Aljaaidi, 2020). According to the career preferences of international students, the governments of Beijing, Shanghai, Zhejiang and other places have also implemented a series of policies to attract them to return home to contribute to the local economy, such as providing generous subsidies and venture capital to international students (Mok et al., 2020). Furthermore, by exploring the impact of mobility actions in Spain on labor market outcomes and skill development, the author concludes that the probability of foreign students becoming entrepreneurs, working abroad and the improvement of information communication and communication skills has a positive impact after studying abroad (Pinto, 2020).

\section{Research description and methodology}

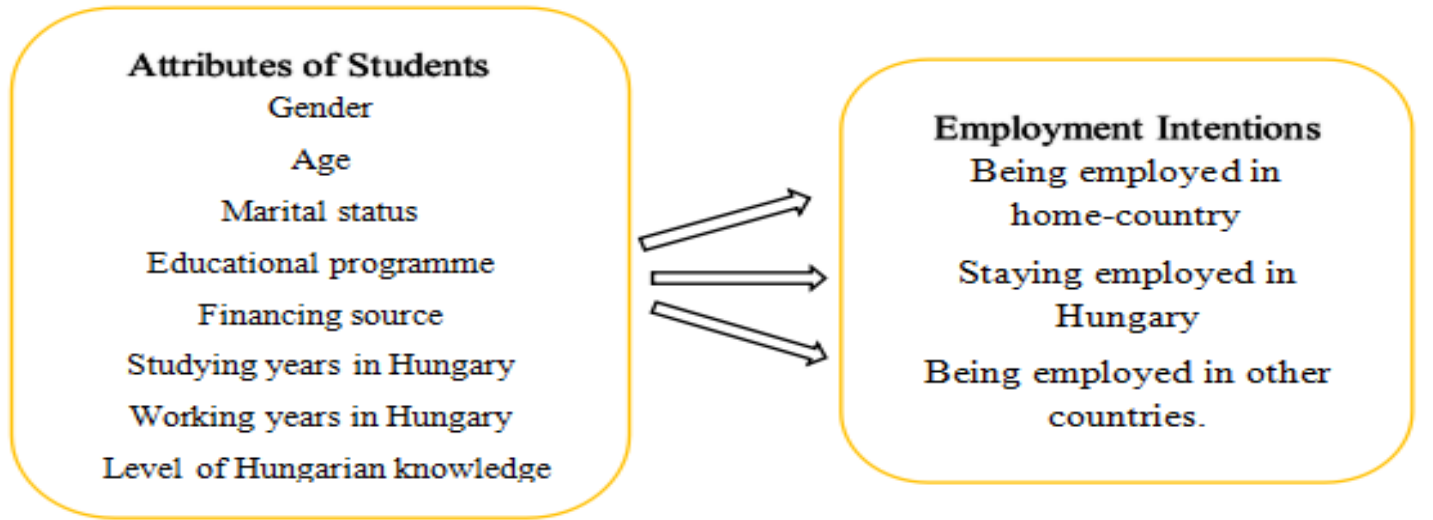

Figure 1. The Model of Theoretical Framework

Source: Own construction (2021)

From the above model (Figure 1), we can see that there are two variables in this study. They are attributes of students variables and employment intentions variables.

This paper used SPSS (version 26.0, IBM Corp., Armonk, NY, USA, 2019) to analyse the data and we divided the data analysis into four sections. The first section is a descriptive analysis of basic information of international students in Hungary, so the descriptive statistics method was used in SPSS. Then, the second section is to analyse whether there is a big difference in the employment intentions of foreign students before and after studying in 


\section{ENTREPRENEURSHIP AND SUSTAINABILITY ISSUES}

ISSN 2345-0282 (online) http://jssidoi.org/jesi/

2021 Volume 8 Number 4 (June)

http://doi.org/10.9770/jesi.2021.8.4(33)

Hungary, here we used Paired-Samples T-Test. The third section is to evaluate whether there are significant relationships between different attributes of international students and different employment intentions. We used the Crosstabulation tool to analyse the relationship between gender, age, marital status, educational program, financing sources, studying years in Hungary, working years in Hungary, level of Hungarian knowledge and three types of employment intentions. In addition, we also found out the preference of employment intentions of international students with different attributes. The last section explores the main reasons for choosing different employment intentions, and here we used descriptive statistical analysis again.

In order to achieve the main purpose of this study, the next step will be the statistical analysis of the data obtained. We put forward the following assumptions for this study:

H1: There is no difference in employment intentions of foreign students to be employed in home-country between before and after studying in Hungary.

$\mathrm{H} 2$ : There is no difference in employment intentions of foreign students to stay employed in Hungary between before and after studying in Hungary.

H3: There is no difference in employment intentions of foreign students to be employed in other foreign countries between before and after studying in Hungary.

H4: There is a significant relationship between the different attributes of foreign students in Hungary and their employment intention to be employed in home-country.

H5: There is a significant relationship between the different attributes of foreign students in Hungary and their employment intention to stay employed in Hungary.

H6: There is a significant relationship between the different attributes of foreign students in Hungary and their employment intention to be employed in other foreign countries.

We undertook the research work and collected data in the form of a survey. This study designed a questionnaire based on the current studying experience in Hungary and research literature of many scholars, combined with the hypothesis and purpose of this paper. The data of this questionnaire were collected through an electronic questionnaire filled out online. According to Tempus Public Foundation (2020), there are 38,422 international students in Hungarian higher education by the academic year 2019/2020. Among them, with the help of the students studying in different universities in Hungary, we collected 448 valid questionnaires that met the requirements of the analysis, and the number of valid responses accounted for $1.17 \%$ of the total number of international students in Hungary.

The questionnaire is divided into three parts: The first part is the basic information of international students currently in Hungary, including gender, age, marital status, educational program, financing source, studying years in Hungary, working years in Hungary, level of Hungarian knowledge and so on. The second part mainly studies whether the international students in Hungary have changed their employment intentions after studying in Hungary. Here, employment intentions are divided into three directions, they are being employed in homecountry, staying employed in Hungary and being employed in other foreign countries. The sample questions including "Before studying in Hungary, I would like to work in my home-country" "After studying in Hungary, I would like to work in Hungary" and the respondent could choose from 1 to 5 ( $1=$ not at all, $5=$ extremely). The third part is the reasons why international students choose different employment intentions. Sample questions includes "After studying abroad, I will get more job opportunities when I return home." "I mastered the Hungarian language and I could easily find a good job." The questions in this part are based on the degree of consent, which are divided into strongly disagree, disagree, moderate, agree and strongly agree. The corresponding scales are 1 to 5 . 


\section{Results of Research}

\subsection{Demographic Analysis of the Sample}

Through the descriptive analysis of SPSS, the following figures reflect the basic information about the respondents' gender, age, marital status, educational program, financing source, studying years in Hungary, working years in Hungary and the level of Hungarian knowledge. As follows,

Gender: Female participants were higher than male participants, compared with $56.7 \%$ females and $43.3 \%$ males. Age: Most participants were younger than 23 years old (44.6\%), followed by 24-28 years old (35.7\%), but more than 29 years old (19.6\%) were relatively fewer (Figure 2).

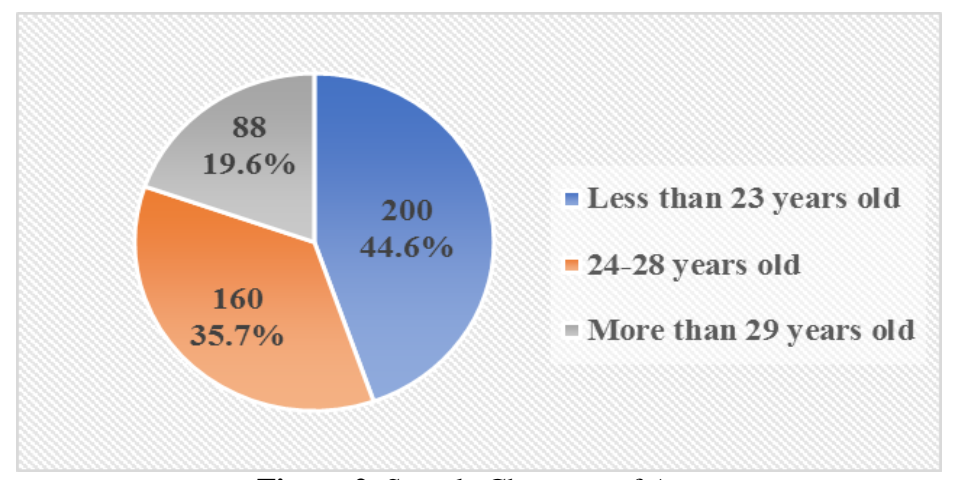

Figure 2. Sample Character of Age

Source: Own construction (2021)

Marital status: $88.8 \%$ of participants were single, while fewer participants were married and divorced/widowed, with $10.7 \%$ and $0.4 \%$ respectively.

Educational program: Most participants are involved in the degree program, with $44.4 \%$ of participants studying Bachelor course in Hungary followed by Master courses 37.1\% and Doctoral participants 15.2\%. Besides, participants in non-degree courses were $3.4 \%$ in total (Figure 3).

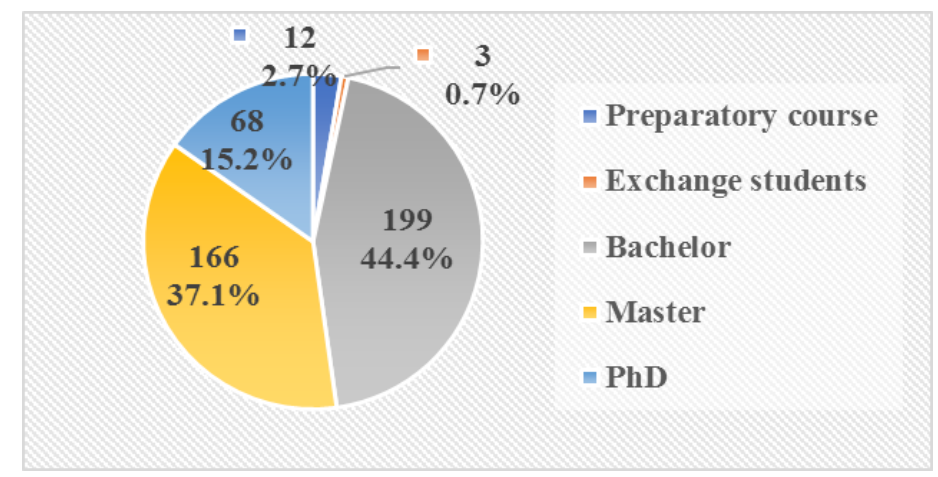

Figure 3. Sample Character of Educational program

Source: Own construction (2021)

Financing source: $66.7 \%$ of participants were awarded scholarships for studying in Hungary, whose number was twice as large as $33.3 \%$ participants at their own expense. 
Study years: Participants mainly have been studying in Hungary for 2-3 years (47.8\%), some participants have been studying for less than one year $(38.4 \%)$. However, there were fewer participants with more than four years of study $(13.8 \%)$.

Work years: Only about $30.4 \%$ of participants had worked in Hungary, including less than one year (21.2\%), 2-3 years $(7.8 \%)$ and more than four years $(1.4 \%)$, while about $69.6 \%$ of participants did not have any work experience during their studies in Hungary (Figure 4).

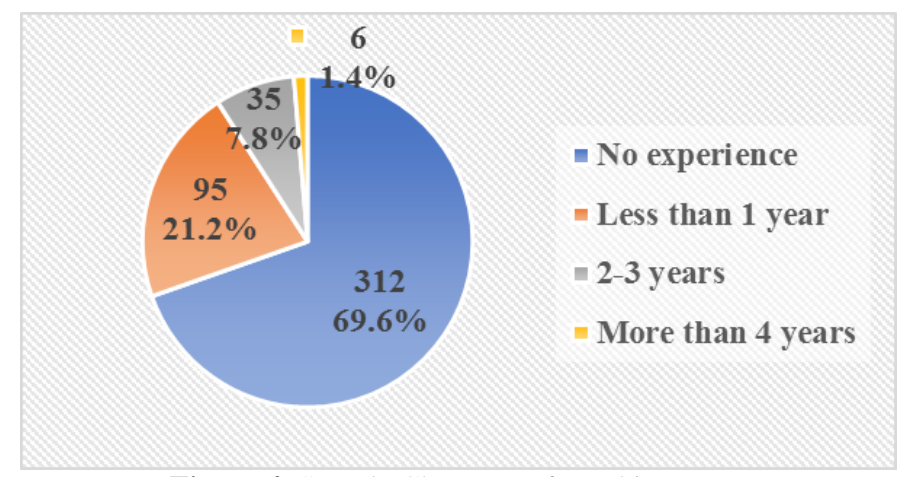

Figure 4. Sample Character of Working years

Source: Own construction (2021)

Level of Hungarian knowledge: Most participants studying in Hungary do not speak Hungarian accounting for $69.4 \%$, while about $30.6 \%$ of participants can speak Hungarian, but few participants speak Hungarian proficiency accounting for only $0.9 \%$ (Figure 5).

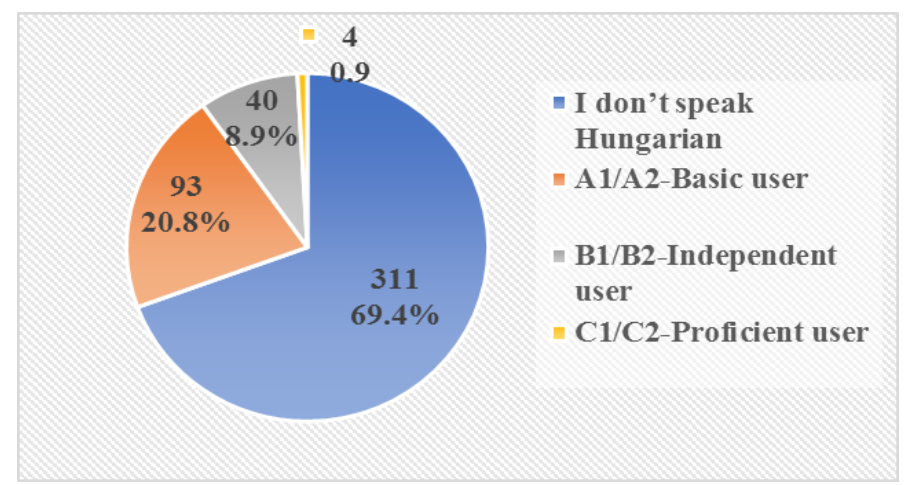

Figure 5. Sample Character of Hungarian knowledge level

Source: Own construction (2021)

\subsection{Reliability}

Here, Cronbach's alpha test was used to check the reliability of the scale. The ideal value of Cronbach alpha coefficient for a scale is greater than 0.7 (DeVellis, 2016). As can be seen from Table 1 that the employment intentions of international students before and after studying in Hungary include being employed home-country, staying employed in Hungary and being employed in other foreign countries. Their Cronbach Alpha values are 0.747, 0.708 and 0.786 , respectively, suggesting that the items are considered acceptable, so the survey data are expected to produce pragmatic results. 


\section{ENTREPRENEURSHIP AND SUSTAINABILITY ISSUES}

ISSN 2345-0282 (online) http://jssidoi.org/jesi/

2021 Volume 8 Number 4 (June)

http://doi.org/10.9770/jesi.2021.8.4(33)

Table 1. Cronbach's Alpha Reliability

\begin{tabular}{lccc}
\hline $\begin{array}{l}\text { Before- After studying } \\
\text { in Hungary }\end{array}$ & $\begin{array}{c}\text { Cronbach's } \\
\text { Alpha }\end{array}$ & $\begin{array}{c}\text { Cronbach's Alpha Based on } \\
\text { Standardized Items }\end{array}$ & $\begin{array}{c}\text { N of Items } \\
\text { Being employed in home-country }\end{array}$ \\
Staying employed in Hungary & 0.747 & 0.747 & 2 \\
Being employed in other foreign countries & 0.708 & 0.709 & 2 \\
\hline
\end{tabular}

Source: Own construction (2021)

\subsection{The difference in the employment intentions of foreign students before and after studying in Hungary}

According to the results of the Paired-Sample T-Test, Table 2 shows that the P-value of being employed in homecountry is greater than 0.05, while the P-values of employment in Hungary and other foreign countries are less than 0.05. As Sig. (2-tailed) are significant at 5\% level of significance $(\mathrm{p}<0.05)$, so we conclude that there is no significant difference for foreign students' employment intention in their own country before and after studying in Hungary $(\mathrm{p}>0.05)$. However, there is a significant difference for being employed in Hungary and in other foreign countries $(\mathrm{p}<0.05)$.

By comparing the mean values of the three employment intentions, the results show that international students have the strongest desire to return to their own country for employment, followed by being employed in other foreign countries and lastly employment in Hungary.

Furthermore, before and after studying in Hungary, the largest gap in the willingness of international students is to stay employed in Hungary (0.34), followed by employment in other foreign countries (0.30) and then employment in their own country (0.09). These means that after studying in Hungary, the willingness of international students to stay and work in Hungary has increased most obviously, and the willingness to work in other countries has also been correspondingly increased, but the willingness to return to their own country has not been changed much.

Table 2. Paired Samples T-Test for employment intentions foreign students before and after studying in Hungary

\begin{tabular}{|l|l|c|c|c|c|}
\hline & $\begin{array}{c}\text { Comparison of employment intentions before } \\
\text { and after studying in Hungary }\end{array}$ & Mean & $\begin{array}{c}\text { Paired } \\
\text { Differences } \\
\text { Mean }\end{array}$ & $\begin{array}{c}\text { Std. } \\
\text { Deviation }\end{array}$ & $\begin{array}{c}\text { Sig. } \\
\text { (2-sided) }\end{array}$ \\
\hline Pair 1 & Be employed in home-country---Before & 3.64 & 0.09 & 1.174 & .075 \\
& Be employed in home-country---After & 3.55 & & 1.187 & \\
\hline Pair 2 & Stay employed in Hungary---Before & 2.54 & 0.34 & 1.227 & .000 \\
& Stay employed in Hungary---After & 2.88 & & 1.279 & .000 \\
\hline Pair 3 & Be employed in other foreign countries---Before & 2.89 & 0.30 & 1.296 & .000 \\
& Be employed in other foreign countries---After & 3.19 & & 1.322 & \\
\hline
\end{tabular}

Source: Own construction (2021)

4.4 The relationship between different attributes of international students and different employment intentions before studying in Hungary

Here, we used Crosstabulation Test to detect whether there are relationships between variables. If Pearson Chisquare significance $(\mathrm{p})$ is less than 0.05 , there exists a significant relationship between variables. In order to facilitate viewing and analysis, we deleted variables with P-values greater than 0.05 from the Table 3 and Table 4, and only meaningful variables are retained $(\mathrm{P}<0.05)$. As shown in Table 3 , the $\mathrm{P}$-values of the age, marital status, 
educational program, working years and Hungarian knowledge level of the participants are less than 0.05 , so some of the attributes of the participants have a significant relationship with their employment intentions to work in their home country and to stay employed in Hungary before coming to study in Hungary.

Furthermore, participants aged over 29 who were studying for doctorates are more likely to work in their own countries. In addition, participants with no work experience or less than one year of work experience and those who do not speak Hungarian or only have the Hungarian level of A1/A2 are more likely to work in their own countries after graduation. With regard to employment in Hungary, single participants at the ages of 24-28 are more likely to stay in Hungary. Besides, participants who are studying for Bachelor and Master's degrees with more than two years of work experience prefer to stay in Hungary for employment.

Table 3. Crosstabulation Test of students' attributes and employment intentions before studying in Hungary

\begin{tabular}{|c|c|c|c|c|c|c|c|}
\hline \multicolumn{2}{|l|}{ Before studying in Hungary } & 1 & 2 & 3 & 4 & 5 & $\begin{array}{c}\text { Pearson Chi-Square } \\
\text { Asymptotic } \\
\text { Significance } \\
\text { (2-sided) }\end{array}$ \\
\hline \multicolumn{8}{|c|}{ Being employed in home-country } \\
\hline Age & Below 23 years old & $2.0 \%$ & $6.0 \%$ & $39.6 \%$ & $28.1 \%$ & $24.1 \%$ & \multirow{3}{*}{.000} \\
\hline & 24-28 years old & $7.6 \%$ & $15.2 \%$ & $24.1 \%$ & $19.0 \%$ & $34.2 \%$ & \\
\hline & Over 29 years old & $11.4 \%$ & $6.8 \%$ & $17.0 \%$ & $27.3 \%$ & $37.5 \%$ & \\
\hline \multirow[t]{5}{*}{ Educational Programme } & Preparatory course & $0.0 \%$ & $0.0 \%$ & $75.0 \%$ & $16.7 \%$ & $8.3 \%$ & \multirow{5}{*}{.001} \\
\hline & Exchange students & $0.0 \%$ & $0.0 \%$ & $50.0 \%$ & $50.0 \%$ & $0.0 \%$ & \\
\hline & Bachelor & $3.5 \%$ & $9.0 \%$ & $36.7 \%$ & $26.1 \%$ & $24.6 \%$ & \\
\hline & Master & $7.3 \%$ & $12.2 \%$ & $22.0 \%$ & $20.1 \%$ & $38.4 \%$ & \\
\hline & $\mathrm{PhD}$ & $10.3 \%$ & $5.9 \%$ & $19.1 \%$ & $32.4 \%$ & $32.4 \%$ & \\
\hline \multirow[t]{4}{*}{ Work years } & No experience & $3.9 \%$ & $6.8 \%$ & $29.9 \%$ & $26.7 \%$ & $32.8 \%$ & \multirow{4}{*}{.000} \\
\hline & Below 1 year & $5.3 \%$ & $16.8 \%$ & $28.4 \%$ & $21.1 \%$ & $28.4 \%$ & \\
\hline & 2-3 years & $18.2 \%$ & $12.1 \%$ & $30.3 \%$ & $21.2 \%$ & $18.2 \%$ & \\
\hline & Over 4 years & $50.0 \%$ & $16.7 \%$ & $33.3 \%$ & $0.0 \%$ & $0.0 \%$ & \\
\hline \multirow{4}{*}{ Age } & in Hungary & & & & & & \multirow{4}{*}{.000} \\
\hline & Below 23 years old & $14.1 \%$ & $39.2 \%$ & $27.6 \%$ & $15.1 \%$ & $4.0 \%$ & \\
\hline & 24-28 years old & $30.4 \%$ & $19.0 \%$ & $22.8 \%$ & $17.7 \%$ & $10.1 \%$ & \\
\hline & Over 29 years old & $39.8 \%$ & $10.2 \%$ & $25.0 \%$ & $15.9 \%$ & $9.1 \%$ & \\
\hline \multirow[t]{3}{*}{ Marital status } & Single & $22.8 \%$ & $28.6 \%$ & $26.3 \%$ & $16.7 \%$ & $5.6 \%$ & \multirow{3}{*}{.000} \\
\hline & Married & $43.8 \%$ & $8.3 \%$ & $18.8 \%$ & $8.3 \%$ & $20.8 \%$ & \\
\hline & Divorced/windowed & $0.0 \%$ & $0.0 \%$ & $0.0 \%$ & $100.0 \%$ & $0.0 \%$ & \\
\hline \multirow[t]{5}{*}{ Educational Programme } & Preparatory course & $16.7 \%$ & $33.3 \%$ & $33.3 \%$ & $16.7 \%$ & $0.0 \%$ & \multirow{5}{*}{.000} \\
\hline & Exchange students & $0.0 \%$ & $0.0 \%$ & $0.0 \%$ & $100.0 \%$ & $0.0 \%$ & \\
\hline & Bachelor & $14.1 \%$ & $35.7 \%$ & $30.2 \%$ & $16.1 \%$ & $4.0 \%$ & \\
\hline & Master & $31.1 \%$ & $19.5 \%$ & $20.1 \%$ & $17.7 \%$ & $11.6 \%$ & \\
\hline & $\mathrm{PhD}$ & $44.1 \%$ & $14.7 \%$ & $23.5 \%$ & $10.3 \%$ & $7.4 \%$ & \\
\hline \multirow[t]{4}{*}{ Work years } & No experience & $25.1 \%$ & $28.0 \%$ & $25.7 \%$ & $14.8 \%$ & $6.4 \%$ & \multirow{4}{*}{.000} \\
\hline & Below 1 year & $30.5 \%$ & $27.4 \%$ & $18.9 \%$ & $14.7 \%$ & $8.4 \%$ & \\
\hline & 2-3 years & $12.1 \%$ & $12.1 \%$ & $39.4 \%$ & $36.4 \%$ & $0.0 \%$ & \\
\hline & Over 4 years & $0.0 \%$ & $0.0 \%$ & $33.3 \%$ & $0.0 \%$ & $66.7 \%$ & \\
\hline
\end{tabular}




\section{ENTREPRENEURSHIP AND SUSTAINABILITY ISSUES}

ISSN 2345-0282 (online) http://jssidoi.org/jesi/

2021 Volume 8 Number 4 (June)

http://doi.org/10.9770/jesi.2021.8.4(33)

4.5 The relationship between different attributes of international students and different employment intentions after studying in Hungary

Table 4 shows that after studying in Hungary, there are significant relationships between the different attributes of the participants and three different employment intentions $(\mathrm{p}<0.05)$. Specifically, the P-values for working years and Hungarian level of participants who were willing to work in their own countries are both 0.000 . For participants who would like to work in Hungary, the P-values for their gender and working years in Hungary are 0.001, and the P-values for financing source and level of Hungarian language are 0.000. Besides, the P-values of age and financing source of participants who would like to be employed in other foreign countries are 0.010 and 0.003 , respectively. Therefore, we conclude that there is a relationship between the two.

In detail, after studying in Hungary, participants with no work experience or less than one year of work experience are more likely to work in their own country, and most of the participants with 2-3 years of work experience have a moderate attitude towards going back to their home country for employment. Participants with more than 4 years of work experience are likely to be reluctant to go back home to work at all. Participants who do not speak Hungarian or Hungarian level in A1/A2 prefer to work in their own countries, while most of the participants who speak Hungarian in B1/B2 maintain a neutral attitude, but those with higher Hungarian level in $\mathrm{C} 1 / \mathrm{C} 2$ are more reluctant to work at home-country. For those who want to stay and work in Hungary, female participants are more likely to do that than male participants and participants with scholarships to study in Hungary are more likely to do so. With the increase in the number of years of work in Hungary, the desire of participants to work in Hungary has become stronger. In addition, from the perspective of mastering the level of Hungarian, the participants with higher proficiency in Hungarian are more willing to stay and work in Hungary. Concerning employment in other foreign countries, participants over the ages of 29 are more willing to do so. Moreover, compared with self-financed students, scholarships students are more likely to work in other foreign countries.

Table 4. Crosstabulation Test of students' attributes and employment intentions after studying in Hungary

\begin{tabular}{|c|c|c|c|c|c|c|c|}
\hline \multicolumn{2}{|c|}{ After studying in Hungary } & 1 & 2 & 3 & 4 & 5 & $\begin{array}{c}\text { Pearson Chi-Square } \\
\text { Asymptotic } \\
\text { Significance } \\
\text { (2-sided) }\end{array}$ \\
\hline $\begin{array}{l}\text { Being employ } \\
\text { Work years }\end{array}$ & $\begin{array}{r}\text { in home-country } \\
\text { No experience } \\
\text { Below } 1 \text { year } \\
2-3 \text { years } \\
\text { Over } 4 \text { years }\end{array}$ & $\begin{array}{l}3.5 \% \\
14.7 \% \\
12.1 \% \\
83.3 \%\end{array}$ & $\begin{array}{l}8.0 \% \\
8.4 \% \\
21.2 \% \\
16.7 \%\end{array}$ & $\begin{array}{l}26.7 \% \\
34.7 \% \\
42.4 \% \\
0.0 \%\end{array}$ & $\begin{array}{l}31.8 \% \\
25.3 \% \\
6.1 \% \\
0.0 \%\end{array}$ & $\begin{array}{l}29.9 \% \\
16.8 \% \\
18.3 \% \\
0.0 \%\end{array}$ & .000 \\
\hline $\begin{array}{l}\text { Level of Hungarian } \\
\text { Knowledge } \\
\text { Staving em }\end{array}$ & $\begin{array}{l}\text { Don't speak Hungarian } \\
\text { A1/A2-Basic user } \\
\text { B1/B2-Independent user } \\
\text { C1/C2-Proficient user } \\
\text { ved in Hungary }\end{array}$ & $\begin{array}{l}6.5 \% \\
9.7 \% \\
10.0 \% \\
25.0 \%\end{array}$ & $\begin{array}{l}9.7 \% \\
8.6 \% \\
0.0 \% \\
75.0 \%\end{array}$ & $\begin{array}{c}23.4 \% \\
39.8 \% \\
52.5 \% \\
0.0 \%\end{array}$ & $\begin{array}{c}30.2 \% \\
23.7 \% \\
25.0 \% \\
0.0 \%\end{array}$ & $\begin{array}{c}30.2 \% \\
18.3 \% \\
12.5 \% \\
0.0 \%\end{array}$ & .000 \\
\hline Gender & $\begin{array}{c}\text { Male } \\
\text { Female }\end{array}$ & $\begin{array}{l}16.7 \% \\
19.0 \%\end{array}$ & $\begin{array}{l}24.5 \% \\
19.8 \%\end{array}$ & $\begin{array}{l}27.1 \% \\
26.1 \%\end{array}$ & $\begin{array}{l}26.6 \% \\
17.4 \%\end{array}$ & $\begin{array}{l}5.2 \% \\
17.8 \%\end{array}$ & .001 \\
\hline Financing source & $\begin{array}{r}\text { Self-financed } \\
\text { Scholarship }\end{array}$ & $\begin{array}{l}20.8 \% \\
16.6 \%\end{array}$ & $\begin{array}{l}32.9 \% \\
16.2 \%\end{array}$ & $\begin{array}{l}30.2 \% \\
24.7 \%\end{array}$ & $\begin{array}{l}10.7 \% \\
26.7 \%\end{array}$ & $\begin{array}{l}5.4 \% \\
15.9 \%\end{array}$ & .000 \\
\hline Work years & $\begin{array}{l}\text { No experience } \\
\text { Below } 1 \text { year } \\
2-3 \text { years } \\
\text { Over } 4 \text { years }\end{array}$ & $\begin{array}{l}19.6 \% \\
17.9 \% \\
6.1 \% \\
0.0 \%\end{array}$ & $\begin{array}{c}24.4 \% \\
17.9 \% \\
6.1 \% \\
33.3 \%\end{array}$ & $\begin{array}{l}24.8 \% \\
30.5 \% \\
36.4 \% \\
0.0 \%\end{array}$ & $\begin{array}{l}19.6 \% \\
24.2 \% \\
33.3 \% \\
0.0 \%\end{array}$ & $\begin{array}{l}11.6 \% \\
9.5 \% \\
18.2 \% \\
66.7 \%\end{array}$ & .001 \\
\hline Level of Hungarian & Don't speak Hungarian & $22.1 \%$ & $25.0 \%$ & $22.4 \%$ & $20.1 \%$ & $10.4 \%$ & \\
\hline
\end{tabular}




\section{ENTREPRENEURSHIP AND SUSTAINABILITY ISSUES}

ISSN 2345-0282 (online) http://jssidoi.org/jesi/

2021 Volume 8 Number 4 (June)

http://doi.org/10.9770/jesi.2021.8.4(33)

\begin{tabular}{lr|lllll|l}
\hline Knowledge & A1/A2-Basic user & $11.8 \%$ & $17.2 \%$ & $33.3 \%$ & $23.7 \%$ & $14.0 \%$ & \\
& B1/B2-Independent user & $2.5 \%$ & $10.0 \%$ & $45.0 \%$ & $27.5 \%$ & $15.0 \%$ & .000 \\
C1/C2-Proficient user & $0.0 \%$ & $0.0 \%$ & $0.0 \%$ & $0.0 \%$ & $100.0 \%$ & \\
Being employed in other foreign countries & & & & & & \\
Age & Below 23 years old & $16.6 \%$ & $15.6 \%$ & $32.2 \%$ & $19.6 \%$ & $16.1 \%$ & \multirow{2}{*}{.000} \\
24-28 years old & $16.5 \%$ & $20.3 \%$ & $22.8 \%$ & $24.7 \%$ & $15.8 \%$ & \\
Financing source & Over 29 years old & $2.3 \%$ & $18.2 \%$ & $14.8 \%$ & $25.0 \%$ & $39.8 \%$ & \\
& Self-financed & $26.2 \%$ & $16.8 \%$ & $28.9 \%$ & $16.1 \%$ & $12.1 \%$ & \multirow{2}{*}{.000} \\
\hline
\end{tabular}

Source: Own construction (2021)

\subsection{The main reasons for the choice of employment intentions after studying in Hungary}

Through descriptive statistics, we ranked the mean value of the main reasons why international students choose different employment intentions after studying in Hungary. As shown in Table 5, we mainly list the reasons for ranking in the top 5 and believe that they are the main reasons for determining the employment intentions.

Specifically, the main reason for international students who prefer to return to their home countries for employment is that they hope to live in the country where they were born, with a mean value of 4.25 . Secondly, they can get more job opportunities (4.19) and think that the familiar social environment makes them feel more comfortable (4.14) and belonging (4.10). Lastly, they need to take care of their families, which is 4.03. Besides, we further conclude that after graduating from Hungary, the mean values of the first five reasons why international students choose to work in their own country are all greater than 4.0, and the difference between the maximum value and the minimum value is 0.22 .

For international students who are willing to stay and work in Hungary, they like the working environment and atmosphere in Hungary, with 3.75. After that, the living conditions, social security (3.56), cultural and social environment of Hungary (3.51) are also the main reasons for attracting them. In addition, staying and working in Hungary is of great help to international students to increase work experience (3.49) and realize personal ambitions (3.36). The mean values of the first five reasons for international students choosing to work in Hungary are all greater than 3.0 but less than 4.0, and the difference between the maximum and the minimum is 0.39 .

Moreover, the most important reason why Hungarian international students want to work in other foreign countries is that they are more willing to go to countries with better economic standards and social security, which is 4.28. Secondly, they want to broaden their horizons and experience different cultural environments (3.92). A good business environment (3.87) and a variety of job choices (3.73) are also important reasons.

Similar to the reason for international students who want to stay and work in Hungary, they try to improve their work experience in foreign countries to help them find a good job (3.66) when they return home in the future. Here, the mean values of the first five reasons for choosing to work in other foreign countries are all between 4.5 and 3.5, but the difference between the maximum and the minimum is the largest, which is 0.62. 
Table 5. Descriptive statistic of main reasons for the choice of employment intentions after studying in Hungary

\begin{tabular}{|c|c|c|}
\hline Being employed in home-country & Mean Rank & Std. Deviation \\
\hline I hope to live in my own country after graduating from studying in Hungary. & 4.25 & .972 \\
\hline After studying abroad, I will get more job opportunities when I return home. & 4.19 & .830 \\
\hline The familiar social environment of my own country makes me very comfortable. & 4.14 & 1.077 \\
\hline Working in my own country gives me a sense of belonging. & 4.10 & 1.022 \\
\hline $\begin{array}{l}\text { I have the responsibility of taking care of my family, so I need to go back to work } \\
\text { in my own country. }\end{array}$ & 4.03 & 1.103 \\
\hline The mean of all items & 4.142 & 1.001 \\
\hline Staying employed in Hungary & Mean Rank & Std. Deviation \\
\hline I like Hungary's working environment and working atmosphere. & 3.75 & .863 \\
\hline Living conditions and social security in Hungary are better. & 3.56 & 1.099 \\
\hline $\begin{array}{l}\text { I love Hungary's cultural and social environment very much. I would like to settle } \\
\text { down in Hungary after graduation. }\end{array}$ & 3.51 & .966 \\
\hline $\begin{array}{l}\text { Work experience in Hungary can help me find a better job when I return home } \\
\text { country. }\end{array}$ & 3.49 & 1.090 \\
\hline Hungary has the conditions to realize my personal ambition. & 3.36 & 1.091 \\
\hline The mean of all items & 3.534 & 1.022 \\
\hline Being employed in other foreign countries & Mean Rank & Std. Deviation \\
\hline $\begin{array}{l}\text { I would like to work in other countries with better economic development and } \\
\text { social security so that I can get more income. }\end{array}$ & 4.28 & .842 \\
\hline $\begin{array}{l}\text { I would like to work in other countries because I want to go to a new environment. } \\
\text { This can broaden my horizons, let me feel other countries' humanities customs. }\end{array}$ & 3.92 & .961 \\
\hline $\begin{array}{l}\text { I would like to go to a country with a better business environment, which is } \\
\text { conducive to the development of my career. }\end{array}$ & 3.89 & .892 \\
\hline The choice of employment in other foreign countries is diversified. & 3.73 & .963 \\
\hline $\begin{array}{l}\text { Working experience in other foreign countries can help me find a good job when I } \\
\text { return home. }\end{array}$ & 3.66 & 1.064 \\
\hline The mean of all items & 3.896 & 0.944 \\
\hline
\end{tabular}

Source: Own construction (2021)

\section{Discussion}

By using Paired Samples T-Test to analyze employment intentions before and after international students studying in Hungary, we could test the first three hypotheses proposed earlier. According to $\mathrm{P}$ values of Paired Samples T-Test, we conclude that there is no significant difference in employment intentions of international students to be employed in home-country between before and after studying in Hungary, so H1 is not accepted. That is, studying in Hungary has not changed the desire of international students to work in their own country. This result can be related to the research results of Waibel et al. (2017), who concluded that studying abroad may be more likely to reaffirm and promote a selected career path rather than any actual career path change, and the reasons can be explained by the fact that international students with families or other strong relationships in their home countries are expected to reduce the likelihood of considering and planning migration due to expected economic, social and emotional costs (Kley, 2011). However, there exists a great difference in employment intentions to stay employed in Hungary and to be employed in other foreign countries, so $\mathrm{H} 2$ and $\mathrm{H} 3$ are 


\section{ENTREPRENEURSHIP AND SUSTAINABILITY ISSUES}

ISSN 2345-0282 (online) http://jssidoi.org/jesi/

2021 Volume 8 Number 4 (June)

http://doi.org/10.9770/jesi.2021.8.4(33)

acceptable. Those indicate that great changes have taken place in international students' thinking about employment in Hungary and employment in other foreign countries after studying in Hungary. This result is consistent with Parey \& Waldinger (2011) and Kronholz \& Osborn (2016) that studies abroad affect career choices. Moreover, no matter before or after studying in Hungary, most of the international students prefer to work in their own countries, followed by other foreign counties, while the willingness to work in Hungary is not strong enough. Soon (2012)'s research on this view shows that international students who initially intend to return home are more likely to maintain this intention and reduce the likelihood of going to other places. However, after studying abroad, international students' willingness to stay in Hungary has increased, which has contributed to recruiting foreign workers in Hungarian companies, thereby enhancing the diversification level of enterprises.

Through Crosstabulation Test, we examined whether international students' attributes have great relationships with their employment intentions. Here, we mainly verify if the latter three hypotheses previously proposed are accepted. The relationship analysis shows that before studying in Hungary, international students' age, educational programs, years of working and level of mastering Hungary are related to employment in their own countries. After studying in Hungary, international students' working years and level of Hungarian knowledge also have relationships with their intention to work in their own country. Therefore, we infer that most of the attributes of international students are related to employment in their own country so that $\mathrm{H} 4$ is accepted. For employment in Hungary, the age, marital status, educational program and years of working are associated with their intention to stay employed in Hungary before coming to Hungary for studying. After studying in Hungary, their age, financing sources, working years and mastery of Hungarian levels have relationships with their intention of employment in Hungary, therefore H5 is also accepted. Lastly, table 3 does not show any data for any attribute of international students with employment in other foreign countries because we deleted data with Pvalue greater than 0.05. So, we could conclude that before studying in Hungary, there is no significant relationship between international students' attributes and willingness to work in other foreign countries. However, after studying in Hungary, only international students' age and financing source have relationships with their desire to seek employment in other foreign countries. Then, we judge that there is no significant relationship between the variables and $\mathrm{H} 6$ is not accepted.

Combined with before and after studying in Hungary, firstly, we found that age, working years and Hungarian knowledge level are the most important attributes that affect the employment intentions of international students. International students over the age of 29 prefer to work in their own country or work in other foreign countries rather than in Hungary. Then, the more years of international students have worked in Hungary, the more reluctant to return their own country to work, and they are more likely to choose to work in Hungary, especially international students with four years of work experience. Cameron et al. (2019) also pointed out that many international graduates have taken part-time jobs in the host country during their studies. They choose to work in the host country because they are generally familiar with the relevant cultural norms. Besides, with the higher the proficiency of the Hungarian language, the students are more unwilling to return to their own countries for employment and they prefer to work in Hungary. Nilsson \& Ripmeester (2016) also believed that the capability of international students to speak the local language required by the job market of the host country is more advantageous than other factors. Secondly, the attributes that have an impact on the employment intentions of international students are educational programs and financial sources. International students with higher levels of education (masters and doctorates) are more likely to work in their own countries rather than in Hungary. However, Soon (2012)'s study of foreign students in New Zealand showed that doctoral students are less likely to choose to work in their own country, but are more likely to choose other countries / the UK as their intended destination country. In addition, international students in Hungary who have won scholarships are more likely to work in Hungary or work in other foreign countries than self-financed students. Lastly, the remaining attributes are the gender and marital status of international students, but these attributes do not have a great impact on the choice of employment intentions, but they can also be used as reference factors. That is, female international students are more willing to work in Hungary than men, and the same of married international students. 


\section{ENTREPRENEURSHIP AND SUSTAINABILITY ISSUES}

ISSN 2345-0282 (online) http://jssidoi.org/jesi/

2021 Volume 8 Number 4 (June)

http://doi.org/10.9770/jesi.2021.8.4(33)

In addition to testing the above hypotheses, this paper also explored the reasons for choosing different employment intentions after studying in Hungary. Compared with the three employment intentions, we found that the mean value of all items of employment in home-country is the highest, which is $\Sigma 4.142$. This is followed by employment in other foreign countries $(\Sigma 3.896)$ and employment in Hungary $(\Sigma 3.534)$. These indicate that international students in Hungary have a high degree of recognition for the same reasons for choosing to return to their own countries for employment, followed by employment in other foreign countries. However, the recognition of international students who stay employed in Hungary for the same reason is relatively low. In addition, what is interesting is that the mean ranking of the reasons for choosing three different employment intention is the same as the mean ranking order of choosing employment intentions before and after studying in Hungary.

\section{Conclusion and Suggestion}

For both the home country and the host country of foreign students, it is imperative for policy makers to understand the employment intentions of foreign students (Soon, 2012). Rowthorn (2008) believed that international students are highly skilled foreign workers who account for almost all of the contribution of international workers to the economy of the host country. In addition, the view of the labor market of the host country has a great influence on the intention of international students to stay in the host country after graduation (Baruch et al., 2007). Here, Blackmore et al. (2017)'s advice for international graduates planning is that to stay in host country is not only to comply with the immigration policies of the host country, but also to understand the more subtle rules and expectations of the local labour market, such as different cultural preferences and social fields.

Moreover, the excellent language skills generated by studying abroad can bring sustainable advantages to entering the labour market because it is an attractive selection criterion for employers, which in turn enhances the sustainability of their employment (Choi et al., 2020). In addition, entrepreneurial education has a great and positive impact on entrepreneurial self-efficacy and students' attitude towards entrepreneurship as well as needs more support from the government to promote the development of entrepreneurial activities (Tung et al., 2020). Therefore, the role of universities in entrepreneurship education programs is crucial. The creation of entrepreneurship and training programs can promote and support students' entrepreneurial behavior, that is, students' entrepreneurial skills will be improved, thus further putting knowledge into practice (Fernandes et al., 2018).

This article could provide some data reference for policy makers of Hungarian government, universities, and enterprises. Therefore, the Hungarian government could adjust the educational mobility program or take further actions, universities could strengthen the training of international students in Hungarian, career skills and entrepreneurial awareness. At the same time, for Hungarian enterprises that would like to improve the level of diversification, they need to provide more internship opportunities for international students, so as to enhance the work experience of international students. In this way, they will also be more willing to stay and work in Hungary. 


\section{ENTREPRENEURSHIP AND SUSTAINABILITY ISSUES}

ISSN 2345-0282 (online) http://jssidoi.org/jesi/

2021 Volume 8 Number 4 (June)

http://doi.org/10.9770/jesi.2021.8.4(33)

\section{References}

Arthur, N., \& Flynn, S. (2011). Career development influences of international students who pursue permanent immigration to Canada. International Journal for Educational and Vocational Guidance, 11(3), 221-237. http://dx.doi.org/10.1007/s10775-011-9212-5

Baruch, Y., Budhwar, P. S., \& Khatri, N. (2007). Brain drain: Inclination to stay abroad after studies. Journal of world business, 42(1), 99112. http://dx.doi.org/10.1016/j.jwb.2006.11.004

Bañegil-Palacios, T. M., \& Sánchez-Hernández, M. I. (2018). The challenge to foster foreign students' experiences for sustainable higher educational institutions. Sustainability, 10(2), 495. http://dx.doi.org/10.3390/su10020495

Blackmore, J., Gribble, C., \& Rahimi, M. (2017). International education, the formation of capital and graduate employment: Chinese accounting graduates' experiences of the Australian labour market. Critical Studies in Education, 58(1), 69-88. http://dx.doi.org/10.1080/17508487.2015.1117505

Brooks, R., Waters, J., \& Pimlott - Wilson, H. (2012). International education and the employability of UK students. British Educational Research Journal, 38(2), 281-298. http://dx.doi.org/10.1080/01411926.2010.544710

Cameron, R., Farivar, F., \& Coffey, J. (2019). International graduates host country employment intentions and outcomes: Evidence from two Australian universities. Journal of Higher Education Policy and Management, 41(5), 550-568. http://dx.doi.org/10.1080/1360080X.2019.1646383

Choi, D., Chung, C. Y., Yoon, M., \& Young, J. (2020). Factors in a Sustainable Labor Market: Evidence from New College Graduates' Initial Job Placement in Korea. Sustainability, 12(6), 2386. http://dx.doi.org/10.3390/su12062386

DeVellis, R. F. (2016). Scale development: Theory and applications (Vol. 26): Sage publications.

European Migration Network. (2018). Attracting and retaining international students in the EU. Retrieved from Hungary: https://ec.europa.eu/home-affairs/sites/homeaffairs/files/13a_hungary_attracting_retaining_students_en_0.pdf

European Union. (2020). Erasmus+ Annual Report. Retrieved from Luxembourg: https://op.europa.eu/en/publication-detail//publication/30af2b54-3f4d-11eb-b27b-01aa75ed71a1/language-en\%20\%20P10

Fernandes, C., Ferreira, J. J., Raposo, M., Sanchez, J., \& Hernandez-Sanchez, B. (2018). Determinants of entrepreneurial intentions: an international cross-border study. International Journal of Innovation Science, 10(2), 129-142. https://doi.org/10.1108/IJIS-02-2017$\underline{0017}$

Gill, S. (2010). The homecoming: an investigation into the effect that studying overseas had on Chinese postgraduates' life and work on their return to China. Compare, 40(3), 359-376. http://dx.doi.org/10.1080/03057920903464555

Grogger, J., \& Hanson, G. H. (2015). Attracting talent: Location choices of foreign-born PhDs in the United States. Journal of Labor Economics, 33(S1), S5-S38. http://dx.doi.org/10.1086/679062

Harrison, N. (2012). Investigating the impact of personality and early life experiences on intercultural interaction in internationalised universities. International Journal of Intercultural Relations, 36(2), 224-237. http://dx.doi.org/10.1016/j.ijintrel.2011.03.007

Imran, N., Azeem, Z., Haider, I. I., Amjad, N., \& Bhatti, M. R. (2011). Brain drain: post graduation migration intentions and the influencing factors among medical graduates from Lahore, Pakistan. BMC research notes, 4(1), 1-5. http://dx.doi.org/10.1186/1756-0500-4-417

Kley, S. (2011). Explaining the stages of migration within a life-course framework. European sociological review, 27(4), 469-486. http://dx.doi.org/10.1093/esr/jcq020

Kronholz, J. F., \& Osborn, D. S. (2016). The Impact of Study Abroad Experiences on Vocational Identity among College Students. Frontiers: The Interdisciplinary Journal of Study Abroad, 27, 70-84. http://dx.doi.org/10.36366/frontiers.v27i1.375

Wu, S.; \& Wu, L. 2008. The impact of higher education on entrepreneurial intentions of university students in China, Journal of Small Business and Enterprise Development 15(4): 752-774. https://doi.org/10.1108/14626000810917843 


\section{ENTREPRENEURSHIP AND SUSTAINABILITY ISSUES}

ISSN 2345-0282 (online) http://jssidoi.org/jesi/

2021 Volume 8 Number 4 (June)

http://doi.org/10.9770/jesi.2021.8.4(33)

Mazzarol, T., \& Soutar, G. N. (2002). “Push - pull” factors influencing international student destination choice. International Journal of Educational Management, 16(2):82-90. http://dx.doi.org/10.1108/09513540210418403

Ministry of Education. (2017). 2017 sees increase in number of Chinese students studying abroad and returning after overseas studies [Press release]. Retrieved from http://en.moe.gov.cn/news/press_releases/201804/t20180404_332354.html

Mok, K. H., Lang, S., \& Xiao, H. (2020). The quest for global talent for changing economic needs: A study of student mobility and job prospects for returnees in China. Globalisation, Societies and Education, 18(1), 79-96. http://dx.doi.org/10.1080/14767724.2019.1690734

Mosneaga, A., \& Winther, L. (2013). Emerging talents? International students before and after their career start in Denmark. Population, Space and Place, 19(2), 181-195. http://dx.doi.org/10.1002/psp.1750

Naito, T., \& Zhao, L. (2020). Capital accumulation through studying abroad and return migration. Economic Modelling, 87, 185-196. http://dx.doi.org/10.1016/j.econmod.2019.07.018

Netz, N., \& Jaksztat, S. (2017). Explaining scientists' plans for international mobility from a life course perspective. Research in Higher Education, 58(5), 497-519. http://dx.doi.org/10.1007/s11162-016-9438-7

Nilsson, P. A., \& Ripmeester, N. (2016). International student expectations: Career opportunities and employability. Journal of International Students, 6(2), 614-631. https://www.ojed.org/index.php/jis/article/view/373

OECD. (2020). Education at a Glance 2020. Retrieved from Paris: https://doi.org/10.1787/69096873-en.

Parey, M., \& Waldinger, F. (2011). Studying abroad and the effect on international labour market mobility: Evidence from the introduction of ERASMUS. The economic journal, 121(551), 194-222. http://dx.doi.org/10.1111/j.1468-0297.2010.02369.x

Pinto, F. (2020). The effect of university graduates' international mobility on labour outcomes in Spain. Studies in Higher Education, 1-12. https://doi.org/10.1080/03075079.2020.1725877

Rowthorn, R. (2008). The fiscal impact of immigration on the advanced economies. Oxford review of economic Policy, 24(3), 560-580. http://dx.doi.org/10.1093/oxrep/grn025

Sabaté-Dalmau, M. (2020). Marketing university students as mobile multilingual workers: the emergence of neoliberal lifestylers. International Journal of Multilingualism, 17(1), 11-29. https://doi.org/10.1080/14790718.2020.1682246

Soon, J.-J. (2012). Home is where the heart is? Factors determining international students' destination country upon completion of studies abroad. Journal of Ethnic and Migration Studies, 38(1), 147-162. http://dx.doi.org/10.1080/1369183X.2012.640026

Srovnalikova, P., Kordos, M., Haviernikova K. (2018). Students' Engagement into Family Business in Terms of Cluster Cooperation within Family Businesses. In Soliman, KS. (Ed.) VISION 2020: Sustainable Economic Development and Application of Innovation Management, 32nd Conference of the International-Business-Information-Management-Association (IBIMA), 5079-5088. Sevila: International Business Information Management Association.

Tempus Public Foundation. (2018). International Students in Hungarian Higher Education Institutions. Retrieved from Budapest, Hungary: https://tka.hu/publication/11530/international-students-in-hungarian-higher-education-institutions\%3E

Tempus Public Foundation. (2020). Measuring The Economic Impacts Of Inbound Higher Education Mobility. Retrieved from Budapest, Hungary: https://tka.hu/kiadvany/14367/measuring-the-economic-impacts-of-inbound-higher-education-mobility

Tharenou, P. (2015). Chinese international business graduates: A career dilemma: Repatriate or stay? Journal of Management and Organization, 21(1), 37. http://dx.doi.org/10.1017/jmo.2014.68

Tung, D. T., Hung, N. T., Phuong, N. T. C., Loan, N. T. T., \& Chong, S. C. (2020). Enterprise development from students: The case of universities in Vietnam and the Philippines. International Journal of Management Education, 18(1), 100333. https://doi.org/10.1016/j.ijme.2019.100333 


\section{ENTREPRENEURSHIP AND SUSTAINABILITY ISSUES}

ISSN 2345-0282 (online) http://jssidoi.org/jesi/

2021 Volume 8 Number 4 (June)

http://doi.org/10.9770/jesi.2021.8.4(33)

Waibel, S., Rüger, H., Ette, A., \& Sauer, L. (2017). Career consequences of transnational educational mobility: A systematic literature review. Educational Research Review, 20, 81-98. http://dx.doi.org/10.1016/j.edurev.2016.12.001

Wang, H., \& Liu, Y. (2016). Entrepreneurship and talent management from a global perspective: Global returnees: Edward Elgar Publishing.

Xiong, W., \& Mok, K. H. (2020). Critical Reflections on Mainland China and Taiwan Overseas Returnees' Job Searches and Career Development Experiences in the Rising Trend of Anti-globalisation. Higher Education Policy, 1-24. http://dx.doi.org/10.1057/s41307-020-00185-y

Janka BETÁKOVÁ, assoc. prof., Ing. Arch. PhD., is the asscoiated professor of Management at DTI University, Dubnica nad Váhom, Slovakia. Her research interest is focused on management, regional and space management and marketing. She publishes a number of publications, both in domestic and international journals and she is a co-author of scientific monograhps. She has participated in several domestic and international scientific projects.

ORCID ID: orcid.org/0000-0002-9317-6317

Róbert MAGDA prof., PhD., is a professor, at Szent István University, Faculty of Economics and Social Sciences, Institute of Economics, Law and Methodology and an extra ordinary professor at School of Management Sciences Faculty of Economic and Management Sciences, North-West University, South Africa. During his research activities, he has gained insight into several fields of research, which include but are not limited to the following: the examination of land as a natural and economic resource; different modes of land use; the economic role of natural resources; the economic potentials of rural areas; limited resources and sustainability. In these research areas, he published a series of publications with his colleagues and students, both in domestic and international journals and books.

ORCID ID: orcid.org/0000-0001-9350-6673

Ildikó RUDNÁK, assoc. prof., PhD., is an associate professor at Szent István University, Faculty of Economics and Social Sciences. Her main field of research is multiculturalism, organizational culture, training - coaching, culture shock, labour market, which ones she examines mainly in an international context from the perspective of globalization. Her numerous publications have appeared in domestic and international journals and conference proceedings, she is supervisor of several doctoral students.

ORCID ID: orcid.org/0000-0003-1352-2126

Jingjing WU, PhD-student of Doctoral School in Economics and Regional Studies at Szent István University, Faculty of Economics and Social Sciences. She got the master's degree in management and leadership at Szent István University. Her research field is the multicultural management styles of Chinese enterprises and international labor market.

ORCID ID: orcid.org/0000-0002-4502-2460

Make your research more visible, join the Twitter account of ENTREPRENEURSHIP AND SUSTAINABILITY ISSUES: @Entrepr69728810

Copyright (C) 2021 by author(s) and VsI Entrepreneurship and Sustainability Center

This work is licensed under the Creative Commons Attribution International License (CC BY).

http://creativecommons.org/licenses/by/4.0/

(c) (i) Open Access 